\title{
Dislocation Substructures in Hot-deformed Ni-based Alloys: Simulation for Structure Evolution of Hot-worked Austenite in Low Carbon Steels
}

\author{
Yoshitaka ADACHI, Toshiro TOMIDA and Shigeharu HINOTANI
}

Corporate Research and Development Laboratories, Sumitomo Metal Industries, Ltd., 1-8 Fuso-cyo, Amagasaki, Hyogo 660-0891 Japan

\begin{abstract}
The dislocation substructure in compressively deformed fcc $70 \mathrm{Ni}-30 \mathrm{Fe}$ and $67 \mathrm{Ni}-30 \mathrm{Fe}-3 \mathrm{Ti}$ alloys was investigated to understand or model microstructural evolution in austenite of low carbon steels during hot deformation. These Ni-based alloys are expected to show similar deformation characteristics to austenitic steels because of similar stacking fault energy. The deformation substructure depended in particular on deformation temperature. Below $700^{\circ} \mathrm{C}$ a heavy deformation ( $70 \%$ reduction) introduced microbands, while above $800^{\circ} \mathrm{C}$ it produced equiaxed dislocation cell structures with some partially recrystallized austenite grains. Crystallographic misorientation in microband structures tended to be larger than that in cell structures at the fixed strain and temperature. Preexisting precipitates effectively suppressed the growth of austenite grains recrystallized after deformation, which resulted in macroscopically homogeneous dislocation substructures consisting of microbands. The temperature dependence of dislocation substructures may closely relate to the mechanism of diffusional transformation to ferrite at very low temperature $\sim 500^{\circ} \mathrm{C}$ through strain assisted transformation in low carbon steels.
\end{abstract}

KEY WORDS: hot deformation, substructure, microband, dislocation cell, misorientation, austenite, ultrafine ferrite, strain-induced transformation, strain-assisted transformation.

\section{Introduction}

Transformation of austenite in steels is often susceptible to a strain introduced by pre-transformation deformation. In relation to it, the deformation microstructure of hot worked austenite has been studied over years. However a microstructural change in austenite in steels during hot deformation has not been fully clarified yet mainly because of inevitable transformation to martensite on quenching. Indirect method such as flow curve analysis ${ }^{1)}$ or texture analysis ${ }^{2)}$ has been used to examine the deformation structure. The flow curve analysis provides information on dynamic recrystallization or recovery and texture analysis appears useful for judging whether microstructure is a result of transformation or recrystallization. However such indirect methods often leave doubt. Another approach is to study deformation characteristics of fec alloys and to directly relate these results to low carbon steels. Austenitic stainless steels have been used for the characterization to avoid martensite transformation on quenching to room temperature ${ }^{3)}$. However, stacking fault energy (SFE) strongly affects deformation characteristics such as strainhardening rate and dislocation substructures. For example, it has been reported that in $\mathrm{Ni}-\mathrm{Co}$ alloys ${ }^{4)}$ work-hardening rate in stage III becomes larger and the proportion of equiaxed cells to microbands decrease with decreasing SFE. The deformed stainless steels, therefore, inevitably include different deformation characteristics from low carbon steels because of markedly smaller SFE. A material candidate suitable to such characterization might be fcc $70 \mathrm{Ni}-30 \mathrm{Fe}$ alloy that does not undergo any transformation on quenching and has SFE close to that for low carbon steels at $1100^{\circ} \mathrm{C}$. Hodgson and co-workers have shown using such alloy that heavy deformation applied at $700^{\circ} \mathrm{C}$ by torsion results in the formation of microbands ${ }^{(1)}$. Our aim here is to demonstrate an effect of deformation temperature on dislocation substructures that may operate as intragranular nucleation sites for strain assisted ferrite transformation ${ }^{7)-(1)}$.

\section{Experimental procedure}

Compression experiment was made on $(70-x) \mathrm{Ni}-30 \mathrm{Fe}-$ $x \operatorname{Ti}($ mass $\%)(x=0,1,3)$ alloys using hot deformation equipment. An aim of Ti addition to Ni-Fe alloys is to study the effect of precipitates on deformation substructures, assuming that the addition does not affect the SFE so much. According to the diagram(Fig. 1) $\mathrm{Ni}_{3} \mathrm{Ti}$ precipitates around $900^{\circ} \mathrm{C}$ in $67 \mathrm{Ni}-30 \mathrm{Fe}-3 \mathrm{Ti}$ alloy. The ternary alloys were, therefore, given precipitation treatment at $800^{\circ} \mathrm{C}$ for $600 \mathrm{~s}$ after annealing to cause $\mathrm{Ni}_{3} \mathrm{Ti}$ precipitation.

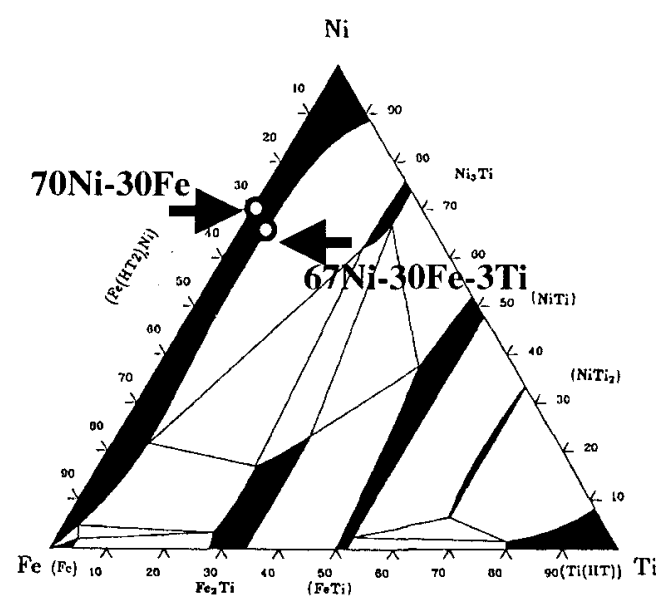

Fig.1 Isothermal section of Ni-Fe-Ti ternary phase diagrams at $900^{\circ} \mathrm{C}$. 
Cylindrical specimens $(8 \mathrm{~mm}$ in diameter, $12 \mathrm{~mm}$ in height) were annealed at $1000^{\circ} \mathrm{C}$ for $300 \mathrm{~s}$ which leads initial grain size to be approximately $100 \mu \mathrm{m}$ in diameter which is almost same with that of the low carbon steel used in accompanying study ${ }^{8)-1(1)}$. Thus in this study the effect of initial grain size on deformation structures and subsequent transformation seems out of issues. The annealed specimens were cooled at the rate of $50 \mathrm{~K} / \mathrm{s}$ down to deformation temperature. Closely following, they were uniaxially deformed up to $70 \%$ in reduction at the range of temperatures between 530 to $800^{\circ} \mathrm{C}$ and immediately quenched to room temperature by $\mathrm{He}$ gas. Microstructural analysis was carried out at the center on the longitudinal section by optical and transmission electron microscopy. Hardness test was also performed. Misorientation was measured from Kikuchi pattern obtained by nano-beam diffraction technique.

\section{Results}

\subsection{Deformation temperature dependence}

A change of hardness is presented in Fig. 2 as a function of deformation temperature and reduction ratio. An increase of hardness with increasing reduction ratio becomes larger as deformation temperature decreases. According to BaileyHirsh equation, average dislocation density( $\rho$ ) (reduction: $70 \%$ ) at $530^{\circ} \mathrm{C}$ is estimated to be about 2.5 times of $\rho(70 \%)$ at $800^{\circ} \mathrm{C}$ (Fig.3), where it is assumed that the relationship between $\rho$ and Vickers hardness $(\mathrm{Hv})$ can be given as

$$
9.8\left(\mathrm{Hv}-\mathrm{Hv}_{0}\right) / 3=1.4 \mu \mathrm{b} \rho^{1 / 2}
$$

, where $\mathrm{Hv}_{0}$ is initial hardness for as-annealed specimens, and $\mu$ and $b$ are modulus of rigidity and Burgers vector of pure $\mathrm{Ni}$, respectively ${ }^{11}$. Therefore it is not surprising that lowering deformation temperature seems more effective for strain accumulation. However it appears questionable to correlate a number of nucleation sites with dislocation density directly since an individual dislocation unlikely operates as a nucleation site for ferrite. Closer microstructural examination should be carried out to clarify the change in microstructure.

TEM micrographs of deformation structures are shown in Fig.4. It might be apparent that the deformation structure depends on, in particular, deformation temperature. As deformation is applied at $800^{\circ} \mathrm{C}$, dislocation cells are mainly introduced with some recrystallized grains( $\uparrow)\left(\right.$ Fig.4(a),(b)), whereas at $530^{\circ} \mathrm{C}$ microbands predominantly form(Fig.4(c),(d)). Deformation at $700^{\circ} \mathrm{C}$ allows both dislocation cells and microbands to form, though later is more often observed. Cell size as well as average spacing of microbands is less than $1 / \mu \mathrm{m}$, which seems independent from reduction ratio in the present study. However both the dislocation cell and the microband develop more with increasing reduction ratio and also appear clearer(Fig. 4(a) $\rightarrow$ (b), (c) $\rightarrow$ (d)) which probably indicates that misorientation becomes larger. Thus comparison of misorientation between microbands and dislocation cells is made with measurement of Kikuchi pattern (Fig.5). By a strain of $70 \%(\varepsilon=1.2)$ at $700^{\circ} \mathrm{C}$, misorientation less than $2^{\circ}$ is often observed in dislocation cell structures, whereas scarcely observed in microbands. In brief deformation at low temperature with high reduction leads the formation of microbands rather than dislocation cells, which consequently results in introduction of closely spaced boundaries with relatively high angle in austenite interiors.

\subsection{Effect of precipitates}

Initial microstructures of $\mathrm{Ni}-\mathrm{Fe}-\mathrm{Ti}$ alloys are demonstrated in Fig.6. Finely dispersed precipitates can be recognized in $67 \mathrm{Ni}-30 \mathrm{Fe}-3 \mathrm{Ti}$, while no precipitates can be observed in $69 \mathrm{Ni}-30 \mathrm{Fe}-1 \mathrm{Ti}$. The precipitates can be defined as $\mathrm{Ni}_{3} \mathrm{Ti}$ from the corresponding diffraction pattern. Contrast around $\mathrm{Ni}_{3} \mathrm{Ti}$ particles appears different from neighbor, which implies that they relate to the matrix with strong orientation relationship. The diffraction pattern also indicates the presence of crystallographic orientation relationship between $\mathrm{Ni}_{3} \mathrm{Ti}$ and matrix austenite.

Comparison in deformation substructures between the precipitate-free alloy $(70 \mathrm{Ni}-30 \mathrm{Fe})$ and the alloy with $\mathrm{Ni}_{3} \mathrm{Ti}$ particles (67Ni-30Fe-3Ti) is made (Fig.7). As deformation is applied at $800^{\circ} \mathrm{C}$, major deformation substructures in $70 \mathrm{Ni}-30 \mathrm{Fe}$ and $67 \mathrm{Ni}-30 \mathrm{Fe}-3 \mathrm{Ti}$ are equiaxed dislocation cells and microbands, respectively. It is also noted that partially recrystallized austenite grains seem much smaller in the later alloy than the former alloy. At $700{ }^{\circ} \mathrm{C}$ microbands become predominant in both alloys and partially recrystallized austenite grains still seem much smaller in the later alloy than the former alloy. As deformation temperature decreases down to $530^{\circ} \mathrm{C}$, only microbands form in both alloys and they often across each

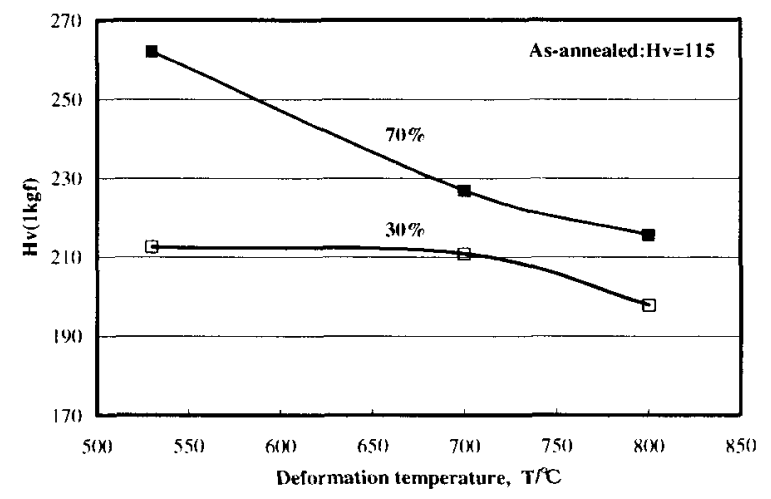

Fig.2 A change of hardness as a function of deformation temperature in $70 \mathrm{Ni}-30 \mathrm{Fe}$ alloy.

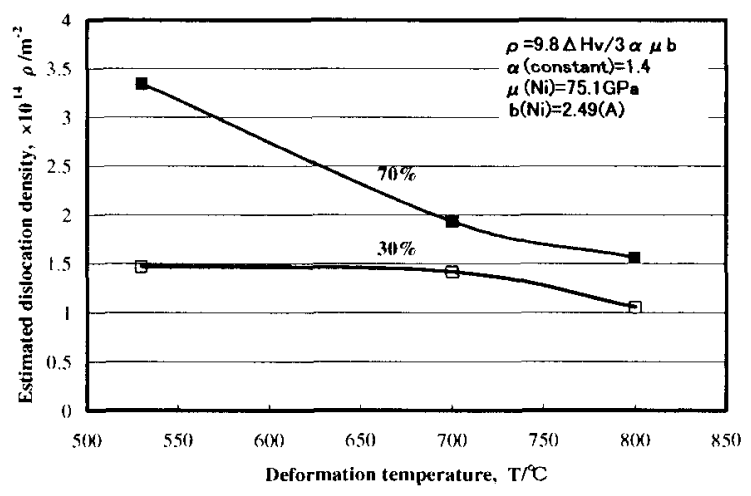

Fig.3 A change of dislocation density as a function of deformation temperature in $70 \mathrm{Ni}-30 \mathrm{Fe}$ alloy. 



Fig.4 Deformation structures formed in 70Ni-30Fe alloy following compression deformation to a strain of (a)(c)30\% and (b)(d) $70 \%$ at a strain rate $5 / \mathrm{s}$ and temperatures of $(\mathrm{a})(\mathrm{b}) 800^{\circ} \mathrm{C}, \quad$ (c) (d) $530^{\circ} \mathrm{C}$. An initial grain size is about $100 \mu \mathrm{m}$ in diameter.
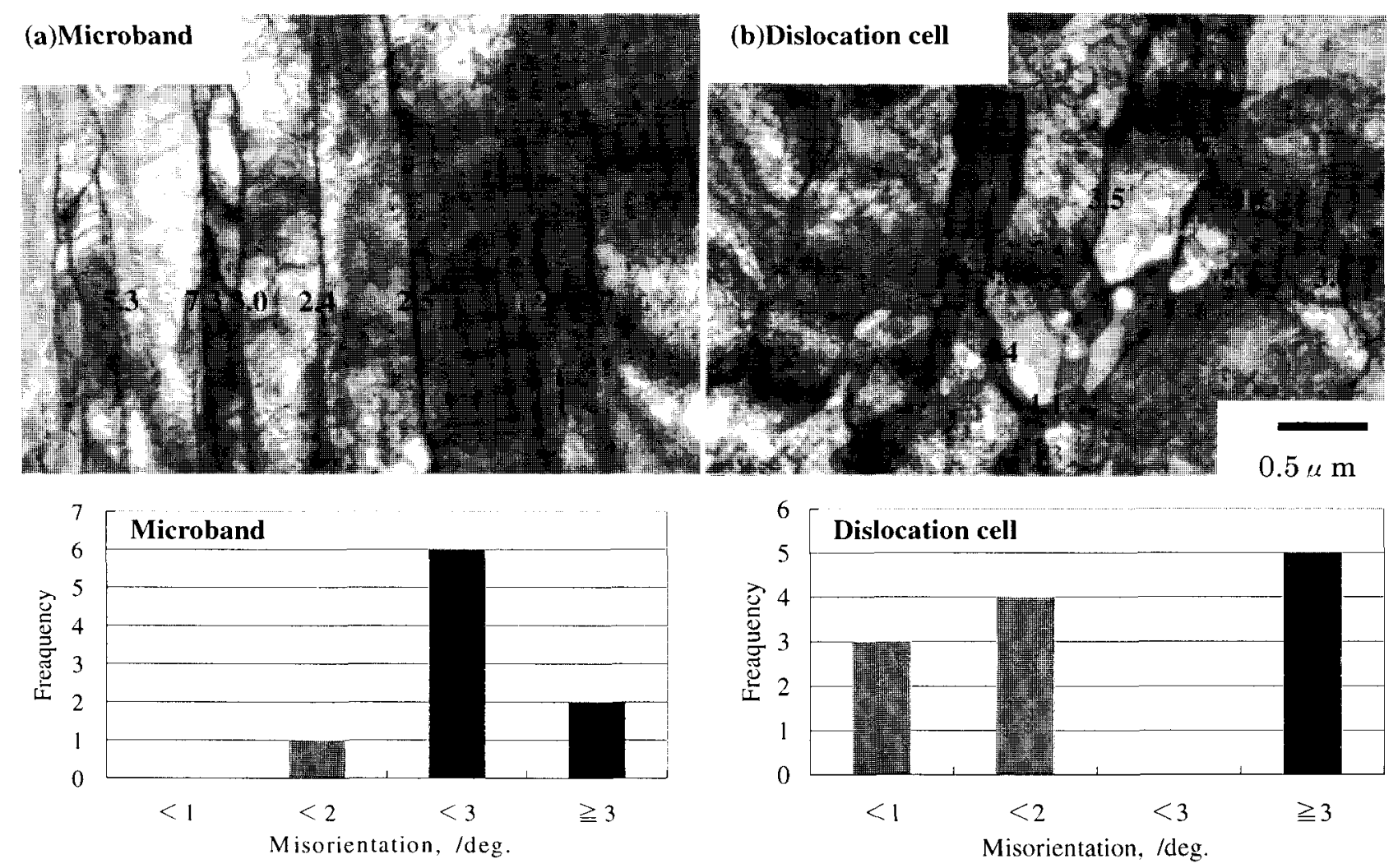

Fig.5 Misorientation of (a) adjacent microbands and of (b) dislocation cells in $70 \mathrm{Ni}-30 \mathrm{Fe}$ alloy. Deformation; $70 \%, 700{ }^{\circ} \mathrm{C}$. 

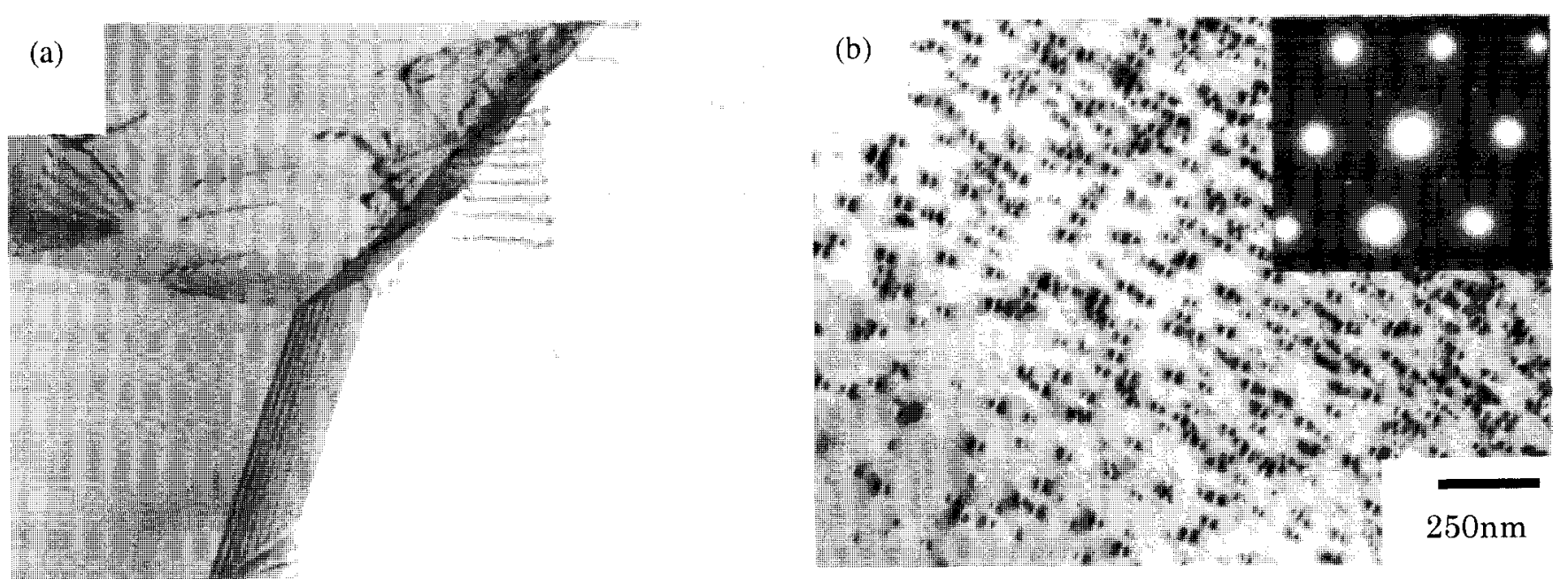

Fig.6 Effect of Ti addition on initial microstructures.

Annealed at $1000^{\circ} \mathrm{C}$ for $5 \mathrm{~min}$, followed by precipitation treatment at $800^{\circ} \mathrm{C}$ for $5 \mathrm{~min}$.

$\begin{array}{ll}\text { (a) } 69 \mathrm{Ni}-30 \mathrm{Fe}-1 \mathrm{Ti} & \text { (b) } 67 \mathrm{Ni}-30 \mathrm{Fe}-3 \mathrm{Ti}\end{array}$
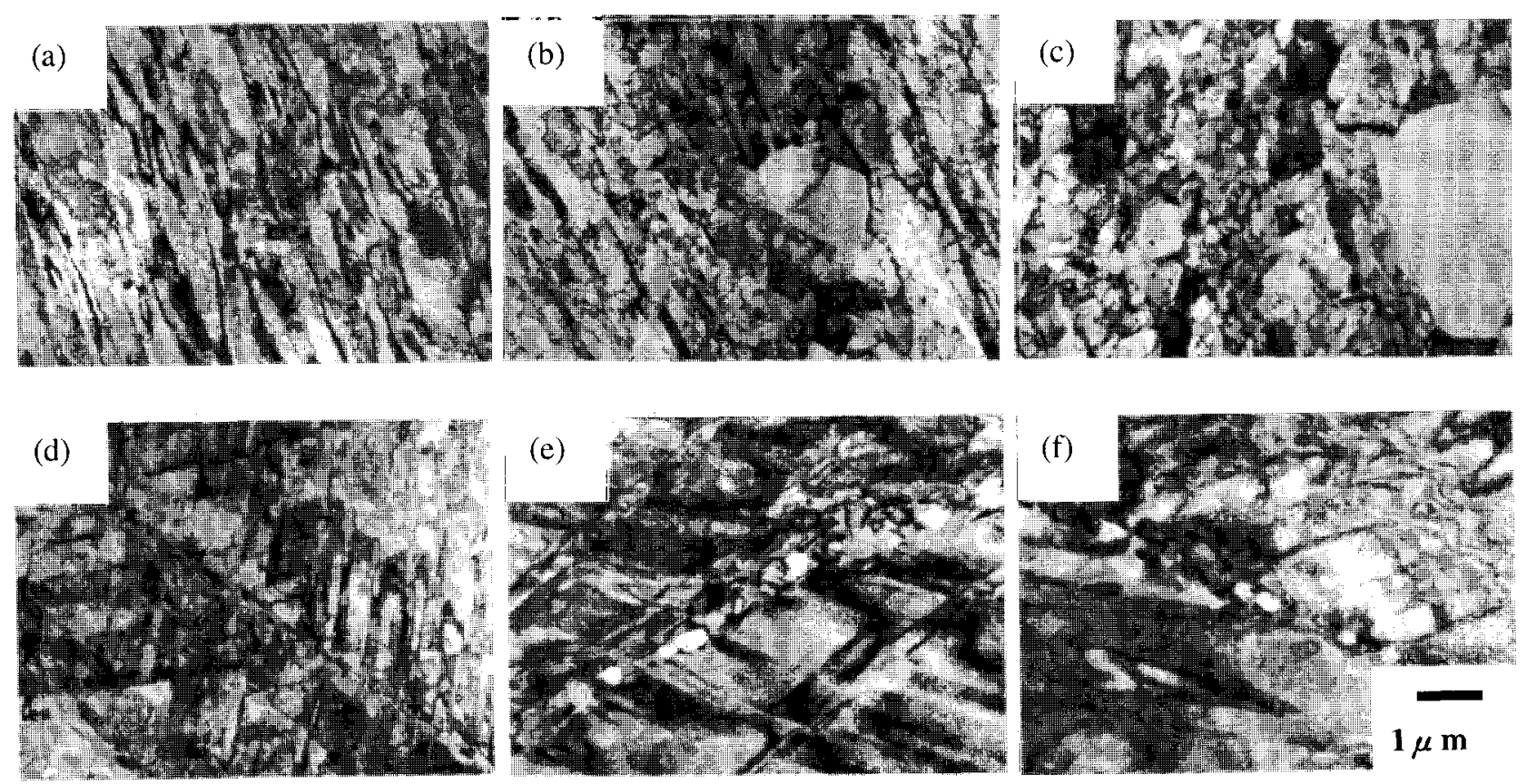

Fig. 7 Comparison of deformation structures between (a)-(c) $70 \mathrm{Ni}-30 \mathrm{Fe}$ and (d)-(f) $67 \mathrm{Ni}-30 \mathrm{Fe}-3 \mathrm{Ti}$ alloys . Deformation temperature: (a) (d) $530^{\circ} \mathrm{C}$, (b) (e) $700^{\circ} \mathrm{C}$, (c) (f) $800^{\circ} \mathrm{C}$

Reduction: (a)-(c), (e)(f) $70 \%$, (d) $45 \%$

other in $67 \mathrm{Ni}-30 \mathrm{Fe}-3 \mathrm{Ti}$ (only Ti-added alloy can not be deformed $70 \%$ at $530{ }^{\circ} \mathrm{C}$ due to high deformation resistance). From observation described above, the effect of Ti addition is probably summarized as follows. By the Ti addition,

(1) heavy deformation introduces microbands instead of dislocation cells even as deformed at relatively high temperature of $800^{\circ} \mathrm{C}$,

(2) growth of recrystallized austenite grains is thoroughly suppressed,

(3) deformation substructures appear more homogeneous than that in $70 \mathrm{Ni}-30 \mathrm{Fe}$, and

(4) difference in deformation substructures between $70 \mathrm{Ni}$ $30 \mathrm{Fe}$ and $67 \mathrm{Ni}-30 \mathrm{Fe}-3 \mathrm{Ti}$ becomes smaller with lowering deformation temperature.

\subsection{Low carbon steels}

It has been shown that equiaxed ferrite grains form in $0.2 \mathrm{C}-0.83 \mathrm{Mn}$ steel as heavy deformation more than $60 \%$ in compression is applied to noticeably supercooled austenite, from which, unless deformed, bainite forms in $\operatorname{common}^{\mathrm{k})-10)}$. Grain size of such strain-assisted ferrite decreases down to $1.2 \mu \mathrm{m}$ with lowering deformation temperature. Namely heavy deformation to significantly supercooled austenite leads ferrite grains to be ultra-refined through strainassisted transformation.

\section{Discussion}

To understand the mechanism of such ferrite formation at very low temperature $\left(-500^{\circ} \mathrm{C}\right)$ in low carbon steels, the microstructural change in mother austenite as a function of 
temperature as well as of strain was investigated using a $70 \mathrm{Ni}-30 \mathrm{Fe}$ alloy. The alloy, which has been proposed as a potentially useful model material for simulating hot deformation process in steel by Herley et al. ${ }^{(6)}$, was deformed at the range of temperatures from $800^{\circ} \mathrm{C}$ down to $530{ }^{\circ} \mathrm{C}$. Lowering deformation temperature leads a predominant deformation substructure to change from dislocation cells to microbands at the strain level of 1.2. As increasing strain at given temperature, substructures are further developed. Misorientation between adjacent microbands is mostly larger than that between adjacent dislocation cells and its average spacing is less than $1 / \mu \mathrm{m}$. In particular since microbands form at relatively low temperatures below $700^{\circ} \mathrm{C}$, where the driving force for ferrite formation becomes higher. The larger undercooling enhances the potency of microbands as ferrite nucleation sites. Therefore microbands likely have higher potency as ferrite nucleation site compared with dislocation cells. Also microbands traversing austenite grains likely suppress or retard the competitive bainite growth into grain interior from austenite grain boundaries. Since bainite relates to austenite with K-S or N-W relationship, the local orientation change at microband boundaries must offer resistance against its growth. Overall, microbands probably enhance nucleation of ferrite more than that of bainite and suppress growth of bainite simultaneously. The combined effects of microbands likely allow the very low temperature diffusional transformation. A pronounced shift of the ferrite transformation field towards higher cooling rates due to the prior austenite deformation has been sometimes reported in the literature ${ }^{12)}$. The large deformation of the austenite, carried out at a non- recrystallization temperature, markedly enhance the ferrite formation in steels with relatively small quench-hardenability, extending its presence in the CCT diagrams to the higher cooling rates. These results may be explained in the same way.

Preexisting precipitates can suppress thoroughly the growth of partially recrystallized austenite grains during hot deformation. This implies that such preexisting precipitates in austenite contribute to homogenize the eventual ferrite microstructures, that is, distribution of ferrite grain size becomes narrower. By the preexistence of precipitates, hot deformation may introduce local orientation change more effectively around them, which may provide further ferrite nucleation sites. A study on the local orientation change due to preexisting precipitates is in progress. In addition such precipitates likely suppresses the growth of ferrite grains. $\mathrm{NbC}$ is one of the candidates to behave as such preexisting precipitates in steels as deformation is applied to significantly supercooled austenite. Actually it has been reported that $\mathrm{Nb}$ addition in steels in conjunction with heavy deformation to markedly supercooled austenite is responsible for homogenizing final ferrite microstructures ${ }^{13)}$ and further reducing ferrite grain size ${ }^{\text {14) (5) }}$.

\section{Conclusions}

In low carbon steels heavy deformation after accelerated cooling allows ferrite to form from significantly supercooled austenite, in which, unless deformed, bainite commonly forms. To understand the mechanism of such low temperature ferrite transformation, evolution of deformation structures in austenite during hot working and the effect of preexisting precipitates on the evolution were studied. The current work has found that:

1) A fec $70 \mathrm{Ni}-30 \mathrm{Fe}$ alloy appears suitable for characterization of evolution of hot-deformed austenite in low carbon steels because of similar SFE.

2) Closely spaced microbands and equiaxed dislocation cells are formed as deformed $70 \%$ at low temperatures below $700^{\circ} \mathrm{C}$ and at high temperatures above $800^{\circ} \mathrm{C}$, respectively.

3) Misorientation less than $2^{\circ}$ is scarcely observed at the interface between adjacent microbands, whereas that is often measured at the dislocation cell boundaries.

4) Due to the relatively high misorientation, microbands probably enhance nucleation of ferrite more than that of bainite and suppress growth of bainite. By the combined effects, microbands likely operate as nucleation sites for strain-assisted ferrite.

5) Preexisting precipitates suppress the growth of partially recrystallized austenite grains very effectively, which results in microstructural homogenization of deformed austenite. This may be responsible for the homogenization of final ferrite microstructures.

\section{Acknowledgements}

This research has been carried out in Ferrous Super Metal Consortium of Japan under the auspices of NEDO.

\section{REFERENCES}

1)H.Yada, Y.Matsumura and T.Senuma: International Conference on Physical Metallurgy of Thermomechanical Processing of Steels and Other Metals (THERMEC-88), Tokyo, (1988), 412. by I.Tamura, ISIJ, Tokyo, (1988), 200.

2)H.Inagaki: Trans. ISIJ, 17(1977), 166

3)S.R.Goodman et al.: Trans. Met. Soc. AIME, 230(1964), 1415.

4) D.A.Hughes and W.D.Nix: Materials Science and Engineering, A122(1989), 153.

5)W.Charnock and J.Nutting: Metal Science Journal, 1(1967), 123 .

6)P.J.Hurley, B.C.Muddle, P.D.Hodgson, C.H.J.Davies, B.P.Wynne, P.Cizek, M.R.Hickson: Materials Science Forum, 284-286 (1998), 159

7)P.D.Hodgson, M.R.Hickson and R.K.Gibbs: Materials Science Forum, 284-286(1998), 63.

8) Y.Adachi,T.Tomida and S.Hinotani: Proceedings of the First Symposium on Super Metal, Tokyo, RIMCOF \&JRCM,(1998), 215 .

9)Y.Adachi, T.Tomida and S.Hinotani: Tetsu-to-Hagane, 85(1999), 620.

10)Y.Adachi,T.Tomida and S.Hinotani: Proceedings of the Second Symposium on Super Metal, Tokyo, RIMCOF \&JRCM,(1999), 135.

11)M.Umemoto: Report of Super Metal, (1999.3), 185

12)Sun Benrong, Zheng Xiuzhen, Zhu Ronglin and Sun Fuyu: Proc. International Conference on Physical Metallurgy of Thermomechanical Processing of Steels and Other Metals (THERMEC-88), Tokyo, (1988), 412.

13)M.R.Hickson and P.D.Hodgson: Materials Science and Technology, 15(1999), 85.

14)Y.Adachi, T.Tomida and S.Hinotani: Tetsu-to-Hagane, 85(1999), 691.

15)M.R.Hickson, R.K.Gibbs and P.D.Hodgson: ISIJ International, 39(1999), 1176 